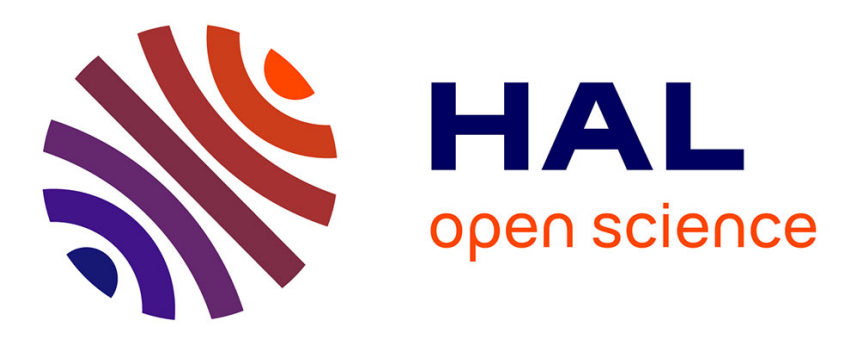

\title{
Melghirimyces thermohalophilus sp. nov., a novel thermoactinomycete isolated from an Algerian salt lake
}

A Addou, P Schumann, Cathrin Sproer, Amel Bouanane-Darenfed, S Amarouche, Hocine Hacene, Jean Luc Cayol, Marie Laure Fardeau

\section{- To cite this version:}

A Addou, P Schumann, Cathrin Sproer, Amel Bouanane-Darenfed, S Amarouche, et al.. Melghirimyces thermohalophilus sp. nov., a novel thermoactinomycete isolated from an Algerian salt lake. International Journal of Systematic and Evolutionary Microbiology, 2012, 63, pp.1717-1722. 10.1099/ijs.0.043760-0 . hal-00805363

\section{HAL Id: hal-00805363 https://hal.science/hal-00805363}

Submitted on 21 Jan 2020

HAL is a multi-disciplinary open access archive for the deposit and dissemination of scientific research documents, whether they are published or not. The documents may come from teaching and research institutions in France or abroad, or from public or private research centers.
L'archive ouverte pluridisciplinaire HAL, est destinée au dépôt et à la diffusion de documents scientifiques de niveau recherche, publiés ou non, émanant des établissements d'enseignement et de recherche français ou étrangers, des laboratoires publics ou privés.

\section{(c)(1)}

Distributed under a Creative Commons Attribution| 4.0 International License 


\section{Melghirimyces thermohalophilus sp. nov., a thermoactinomycete isolated from an Algerian salt lake}

Correspondence

Marie-Laure Fardeau

marie-laure.fardeau@univ-amu.fr

\author{
Ammara Nariman Addou, ${ }^{1,2}$ Peter Schumann, ${ }^{3}$ Cathrin Spröer, ${ }^{3}$ \\ Amel Bouanane-Darenfed, ${ }^{2}$ Samia Amarouche-Yala, ${ }^{4}$ Hocine Hacene, ${ }^{2}$ \\ Jean-Luc Cayol ${ }^{1}$ and Marie-Laure Fardeau ${ }^{1}$ \\ ${ }^{1}$ Aix-Marseille Université, Université du Sud Toulon-Var, CNRS/INSU, IRD, MIO, UM 110, 13288 \\ Marseille Cedex 09, France \\ ${ }^{2}$ Laboratoire de Biologie Cellulaire et Moléculaire (équipe de Microbiologie), Université des \\ sciences et de la technologie, Houari Boumédiènne, Bab Ezzouar, Algiers, Algeria \\ ${ }^{3}$ Leibniz Institut DSMZ - Deutsche Sammlung von Mikroorganismen und Zellkulturen GmbH, \\ Inhoffenstraße 7B, 38124 Braunschweig, Germany \\ ${ }^{4}$ Centre de Recherche Nucléaire d'Alger (CRNA), Algeria
}

A novel filamentous bacterium, designated Nari1 $1 \mathrm{~A}^{\top}$, was isolated from soil collected from a salt lake named Chott Melghir, located in north-eastern Algeria. The strain is an aerobic, halophilic, thermotolerant, Gram-stain-positive bacterium, growing at $\mathrm{NaCl}$ concentrations between 5 and $20 \%(\mathrm{w} / \mathrm{v})$ and at $43-60{ }^{\circ} \mathrm{C}$ and $\mathrm{pH}$ 5.0-10.0. The major fatty acids were iso- $\mathrm{C}_{15: 0 \text {, anteiso- }}$

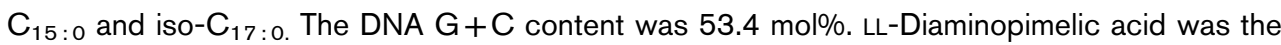
diamino acid of the peptidoglycan. The major menaquinone was MK-7, but MK-6 and MK- 8 were also present in trace amounts. The polar lipid profile consisted of phosphatidylglycerol, diphosphatidylglycerol, phosphatidylethanolamine, phosphatidylmonomethylethanolamine and three unidentified phospholipids. Results of molecular and phenotypic analyses led to the description of the strain as a novel member to the genus Melghirimyces, family Thermoactinomycetaceae. Strain Nari11 $\mathrm{A}^{\top}$ shows $96.7 \% 16 \mathrm{~S}$ rRNA gene sequence similarity to the type strain of Melghirimyces algeriensis. On the basis of phenotypic, physiological and phylogenetic data, strain Nari11 $\mathrm{A}^{\top}$ (=DSM $45514^{\top}=$ CCUG $60050^{\top}$ ) represents the type strain of a novel species, for which the name Melghirimyces thermohalophilus sp. nov. is proposed.
The genus Melghirimyces was described by Addou et al. (2012) with one species, Melghirimyces algeriensis, a thermotolerant and halotolerant filamentous actinomycete first isolated from an Algerian chott. The genus belongs to the family Thermoactinomycetaceae and shares the characteristics of members of this family except for the presence of LL-diaminopimelic acid in the cell wall, which is rather unusual in the family Thermoactinomycetaceae, which is characterized by the presence of meso-diaminopimelic acid (Matsuo et al., 2006). This particular characteristic was also found for the recently isolated species Kroppenstedtia eburnea (Von Jan et al., 2011) and Marininema mesophilum (Li et al., 2012) and has led to the emendation of the description of the family.

The GenBank/EMBL/DDBJ accession number for the $16 \mathrm{~S}$ rRNA gene sequence of strain Nari11 $\mathrm{A}^{\top}$ is JX861508.

Two supplementary figures are available with the online version of this paper.
Here, we characterize a new member of the family Thermoactinomycetaceae isolated from the soil of an Algerian salt lake. The strain was isolated during our investigation of extremophilic actinomycetes with the aim of exploring their potential to produce original bioactive metabolites.

Samples were collected from soil taken from an Algerian salt lake named Chott Melghir located in north-eastern Algeria (located between $34^{\circ} 00^{\prime} 00^{\prime \prime} \mathrm{N} 6^{\circ} 07^{\prime} 30^{\prime \prime} \mathrm{E}$ and $34^{\circ}$ $\left.30^{\prime} 01^{\prime \prime} \mathrm{N} 6^{\circ} 30^{\prime} 02^{\prime \prime} \mathrm{E}\right)$. The soil is characterized by an alkaline $\mathrm{pH}(8.49)$ and a salinity of $112 \mathrm{~g} \mathrm{l}^{-1}$. One gram of the collected soil sample was transferred to $100 \mathrm{ml}$ liquid ISP2 medium (Shirling \& Gottlieb, 1966) supplemented with $10 \% \mathrm{NaCl}$ in a $500 \mathrm{ml}$ flask and incubated in a rotary shaker incubator at $55{ }^{\circ} \mathrm{C}$ with shaking at 160 r.p.m. for 4 days. From this culture, an aliquot of $0.1 \mathrm{ml}$ was inoculated each day onto the surface of solid ISP2 medium with $10 \% \mathrm{NaCl}$; plates were incubated at $55{ }^{\circ} \mathrm{C}$ and monitored after 48, 72 and $96 \mathrm{~h}$. Strain Nari11A ${ }^{\mathrm{T}}$ was 
isolated by this procedure and maintained as a glycerol suspension $(20 \% \mathrm{w} / \mathrm{v})$ at $-80{ }^{\circ} \mathrm{C}$.

Determination of phenotypic and cultural characteristics was achieved by cultivating the strain on ISP media (ISP1, ISP2, ISP4, ISP5, ISP6 and ISP7) as recommended by Shirling \& Gottlieb (1966), and on nutrient agar. All media were supplemented with $10 \% \mathrm{NaCl}$ and incubated at $55{ }^{\circ} \mathrm{C}$. On these media, the colours of aerial and vegetative mycelia and the development of growth were observed. Additionally, the production of melanoid pigments was examined on ISP6 and ISP7.

Cells taken at the exponential phase of growth on nutrient agar for 3 days were used for the study of morphological characteristics under an Optiphot phase-contrast microscope (Nikon). Transmission electron microscopy studies were carried out by using methods described by Fardeau et al. (1997).

Utilization of carbohydrates and organic acids as sole carbon and energy sources was examined on ISP9 medium (Shirling \& Gottlieb, 1966). The same basal medium without $\mathrm{NH}_{4} \mathrm{SO}_{4}$ was used for determination of the utilization of amino acids as sole carbon and nitrogen sources; $10 \%(\mathrm{w} / \mathrm{v}) \mathrm{NaCl}$ was added to the medium. Each substrate tested (Table 1) was added to the medium to a final concentration of $20 \mathrm{mM}$. Mineral medium without carbon source was used as a control. Acid production from carbohydrate utilization was determined by addition of 0.2 g yeast extract $\mathrm{l}^{-1}$ and $20 \mathrm{ml} 0.04 \%(\mathrm{w} / \mathrm{v})$ bromocresol blue solution $1^{-1}$ as $\mathrm{pH}$ indicator to the basal medium. Acidification of the medium was demonstrated by a shift of the colour of the $\mathrm{pH}$ indicator from purple to yellow.

Strain Nari11 ${ }^{T}$ was tested for its ability to grow on meat extract, yeast extract, peptone and Casamino acids (supplied individually at $1 \% \mathrm{w} / \mathrm{v}$ ) as sole carbon and energy sources. Detection of hydrolysis of casein and tyrosine was carried out by the method of Staneck \& Roberts (1974). Hydrolysis of starch was examined as described by Cowan (1974). Aesculin and arbutin agar were used to test the ability of the strain to degrade aesculin and arbutin, respectively, according to the method of Gordon et al. (1974). Hydrolysis of xylan $(0.4 \%$, w/v) was detected on the basal medium of Tsukamura (1966). The method recommended by Sierra (1957) was used to determine the hydrolysis of Tweens 20 and 80. Degradation of xanthine, hypoxanthine, adenine and gelatin was determined according to the method of Gordon (1966) and Gordon \& Mihm (1957). Urease activity was determined according to the method of Lányí (1987). Indole production, the Voges-Proskauer reaction and nitrate reduction/denitrification were investigated by using the methods of Gordon \& Mihm (1957), Guérin-Faublée et al. (1992) and Joffin \& Leyral (2006). The temperature range for growth was determined by incubating the culture on ISP2 medium at temperatures between 30 and $60{ }^{\circ} \mathrm{C}$. The strain was tested at $55{ }^{\circ} \mathrm{C}$ for its ability to grow in the range pH $5-10$ on ISP2 medium buffered with the following solutions: citrate buffer for $\mathrm{pH} 4-6$, Tris/ $\mathrm{HCl}$ for $\mathrm{pH} 7-9$, tetraborate buffer for $\mathrm{pH} 9.5-10$ and $\mathrm{Na}_{2} \mathrm{HPO}_{4}$ buffer for $\mathrm{pH} 11$. For these two tests, the medium was supplemented with $10 \%(\mathrm{w} / \mathrm{v}) \mathrm{NaCl}$. $\mathrm{NaCl}$ requirement for growth of the strain was determined by increasing the amount of $\mathrm{NaCl}$ $(0-20 \% \mathrm{w} / \mathrm{v})$ in the ISP2 medium at $\mathrm{pH} 7$ and at $55^{\circ} \mathrm{C}$.

The phylogenetic position of the strain was established by $16 \mathrm{~S}$ rRNA gene sequencing. The methods of Thabet et al. (2004) were used for DNA purification, PCR amplification and sequencing of the 16S rRNA gene. The partial sequences generated were assembled using BioEdit version 5.0.9 (Hall, 1999) and the consensus sequence of $1532 \mathrm{nt}$ was corrected manually for errors. The most closely related sequences in GenBank (version 178) and the Ribosomal Database Project (release 10) were identified using BLAST (Altschul et al., 1997) and the Sequence Match program (Cole et al., 2009). These sequences were extracted and aligned and the alignment was adjusted manually according to the 16S rRNA secondary structure using BioEdit. Evolutionary distances were calculated by using the Jukes and Cantor option (Jukes \& Cantor, 1969). Dendrograms were reconstructed with the TREECON program using the neighbour-joining method (Saitou \& Nei, 1987). The tree topology was re-examined by the bootstrap method (1000 replications) of resampling (Felsenstein, 1985); its topology was also supported by using the maximum-parsimony and maximum-likelihood algorithms (results not shown).

Biomass for chemotaxonomic and phylogenetic studies was obtained from 72 - to 96 -h-old cultures of strain Nari11 $\mathrm{A}^{\mathrm{T}}$ in ISP6 medium supplemented with $10 \%(\mathrm{w} / \mathrm{v}) \mathrm{NaCl}$ and incubated at $55{ }^{\circ} \mathrm{C}$ under aerobic conditions. Fatty acid methyl esters were obtained following the method of Stead et al. (1992) and were analysed by gas chromatography (model 6890N; Agilent Technologies) using the Microbial Identification System (MIDI; Sherlock version 6.1, TSBA40 database). Polar lipids were determined according to the method described by Minnikin et al. (1979) and separated by two-dimensional TLC. To identify spots, ninhydrin, Zinzadze reagent and molybdophosphoric acid were used (Embley \& Wait, 1994). Isoprenoid quinones were extracted as described by Collins et al. (1977) and analysed by HPLC (Groth et al., 1996).

DNA for the determination of the $\mathrm{G}+\mathrm{C}$ content was obtained after disruption of cells by a French pressure cell (Thermo Spectronic) and purification on hydroxyapatite as described by Cashion et al. (1977). The method of Mesbah et al. (1989) was used for analysis of the DNA base composition and the $\mathrm{G}+\mathrm{C}$ content was determined by reversed-phase HPLC according to the method described by Tamaoka \& Komagata (1984). The G $+\mathrm{C}$ content of the DNA was calculated from the ratio of deoxyguanosine to thymidine.

The isomer of diaminopimelic acid was identified in whole-cell hydrolysates $\left(4 \mathrm{M} \mathrm{HCl}, 100{ }^{\circ} \mathrm{C}, 16 \mathrm{~h}\right)$ by TLC on a cellulose sheet (cat. no. 1.05577.0001; Merck) and sugars were analysed by TLC on cellulose plates after 
Table 1. Characteristics of strain Nari11 $\mathrm{A}^{\top}$ and $M$. algeriensis NariEX

Data for M. algeriensis NariEX ${ }^{\mathrm{T}}$ were taken from Addou et al. (2012). ND, Not determined.

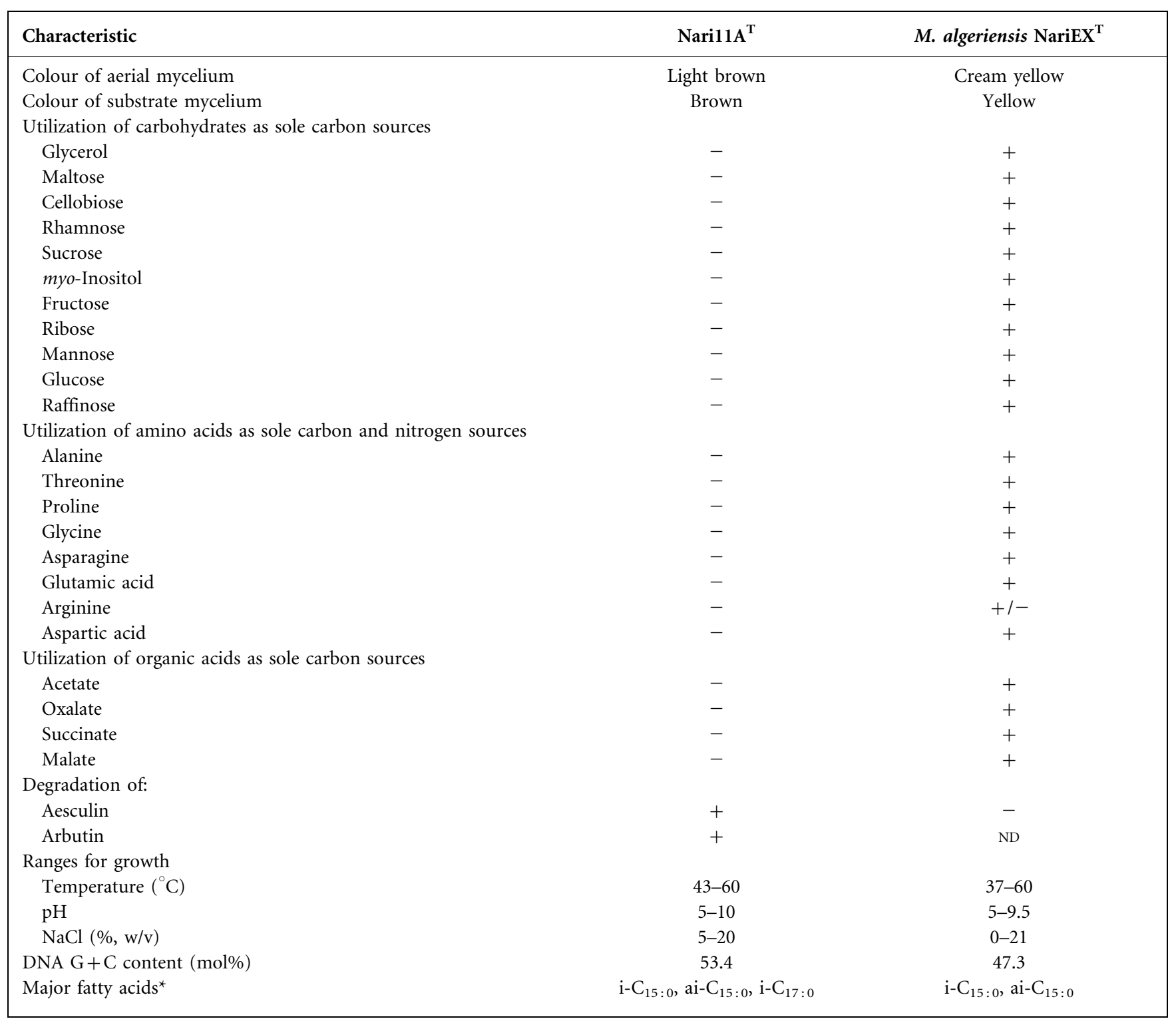

*ai, Anteiso-branched; i, iso-branched.

hydrolysis of whole cells $\left(0.5 \mathrm{M} \mathrm{H}_{2} \mathrm{SO}_{4}, 100{ }^{\circ} \mathrm{C}, 2 \mathrm{~h}\right)$ according to published protocols (Schumann, 2011).

The almost-complete 16S rRNA gene sequence (1514 bp) of strain Naril1A ${ }^{\mathrm{T}}$ was obtained and compared with sequences available in GenBank, indicating that the strain belongs to the genus Melghirimyces. The strain is closely related to $M$. algeriensis, with $96.7 \%$ sequence similarity to the type strain, as shown in the phylogenetic tree (Fig. 1).

Strain Nari11 $\mathrm{A}^{\mathrm{T}}$ formed light-brown aerial mycelium and brown substrate mycelium on ISP 2 medium after $72 \mathrm{~h}$ of incubation at $55{ }^{\circ} \mathrm{C}$. Good growth occurred on ISP1, ISP6 and nutrient agar after $48 \mathrm{~h}$ of incubation at $55^{\circ} \mathrm{C}$.
Moderate growth was observed on ISP7, and no growth was observed on ISP4 or ISP5. Colonies formed on ISP2 medium were dull with irregular margins and radial wrinkles, dark in the centre, clearer at the edges and surrounded by a halo. The diameter was $1.3 \mathrm{~cm}$, and could reach $4 \mathrm{~cm}$ when the culture was incubated for long period. On ISP1 and nutrient agar, the strain formed small, beige colonies, $2-3 \mathrm{~mm}$ in diameter. The best growth was obtained on ISP6, and abundant aerial mycelium was produced as a layer. The strain did not produce any diffusible pigment. Long, straight to flexuous, moderately branched hyphae that developed single endospores were observed by means of phase-contrast microscopy (Figs S1 


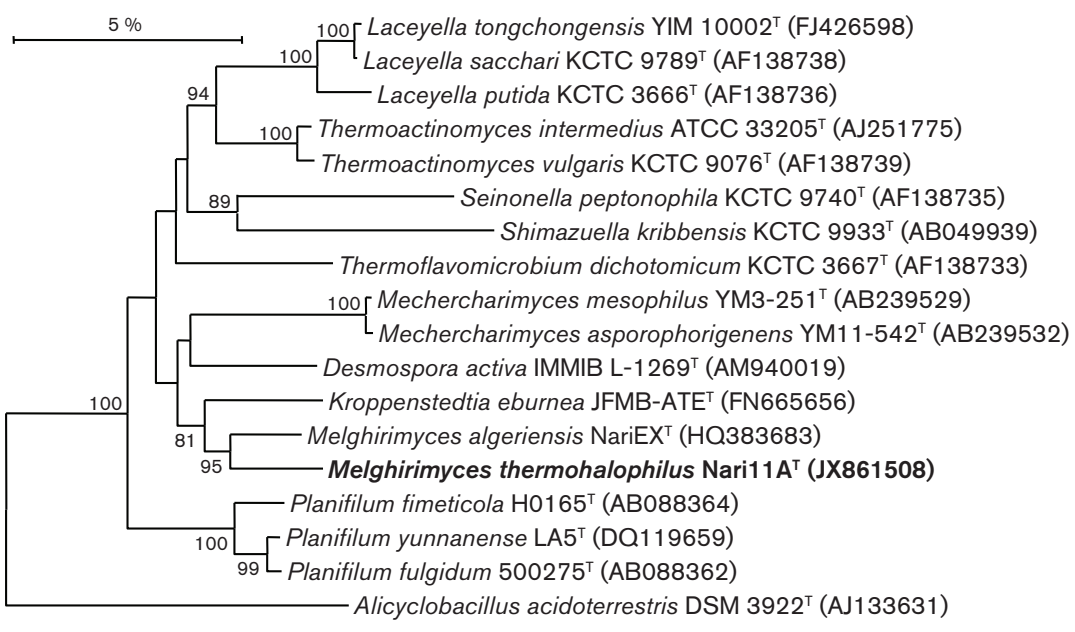

Fig. 1. Neighbour-joining phylogenetic dendrogram based on 1342 unambiguous nucleotides showing the relationship between strain Nari11 $A^{\top}$ and organisms belonging to the family Thermoactinomycetaceae. The dendrogram was reconstructed from 16S rRNA gene sequences. GenBank accession numbers are shown in parentheses. Numbers at branch points specify the reliability of the branching order determined for 1000 resamplings; only bootstrap values above $70 \%$ are shown. Bar, 0.05 substitutions per nucleotide position.

and S2, available in IJSEM Online). The nearest relative $M$. algeriensis showed a similar micromorphology.

Strain Nari11 $\mathrm{A}^{\mathrm{T}}$ was aerobic, Gram-stain-positive, thermophilic and strictly halophilic. Growth occurred at $43-60{ }^{\circ} \mathrm{C}$, with very weak growth at $37{ }^{\circ} \mathrm{C}$. The strain required $\mathrm{NaCl}$ at $5-20 \%(\mathrm{w} / \mathrm{v})$. Very weak growth was observed in $2 \%$ (w/v) $\mathrm{NaCl}$ after 15 days. Unlike the nearest species $M$. algeriensis, which is halotolerant and able to develop on media free of $\mathrm{NaCl}$, the strain is considered as moderately halophilic according to Larsen (1986). This character also distinguishes the new isolate from all other members of the family Thermoactinomycetaceae, for which no halophilic strain has been described so far. Strain Nari11 ${ }^{\mathrm{T}}$ grew at $\mathrm{pH}$ 5-10, with good growth observed at $\mathrm{pH}$ 6-8.

Strain Nari11A ${ }^{\mathrm{T}}$ did not use any of the carbohydrates, amino acids or organic acids tested as sole carbon sources. No growth was observed on ISP9 supplemented with each of the organic compounds used for this test. A similar case has already been reported for another member of the family Thermoactinomycetaceae, namely members of the genus Planifilum, which grow weakly on media containing carbohydrates as sole carbon sources (Hatayama et al., 2005). The species Kroppenstedtia eburnea was also unable to use amino acids as nitrogen sources for growth (Von Jan et al., 2011). This was explained by the fact that the basal media used were not rich enough for examining species of the Thermoactinomycetaceae (Von Jan et al., 2011). This characteristic discriminates strain Nari1 $1 \mathrm{~A}^{\mathrm{T}}$ from the nearest species $M$. algeriensis, which uses many organic compounds as sole carbon sources (Table 1).

Good growth was obtained on yeast extract, peptone and beef extract, while no growth was obtained on Casamino acids. Gelatin, aesculin, arbutin and casein were degraded, while xanthine, hypoxanthine, cellulose, starch, tyrosine, adenine, xylan and Tweens 20 and 80 were not hydrolysed. Urease activity was negative. Nitrate reduction, indole production and the Voges-Proskauer reaction were negative. Results of physiological and biochemical tests are summarized in Table 1.
The DNA G + C content of strain Nari11A ${ }^{\mathrm{T}}$ was $53.4 \mathrm{~mol} \%$, which is much higher than the $\mathrm{G}+\mathrm{C}$ content reported for M. algeriensis $(47.3 \mathrm{~mol} \%)$. The fatty acid profile of strain Nari1 $1 \mathrm{~A}^{\mathrm{T}}$ consisted of iso- and anteiso- $\mathrm{C}_{15: 0}$ and iso- $\mathrm{C}_{17: 0}$ as main components $(34.77,19.38$ and $17.36 \%$, respectively); analysis of cellular fatty acids also revealed the presence of iso- $\mathrm{C}_{11: 0}(0.12 \%)$, anteiso- $\mathrm{C}_{13: 0}(0.38 \%)$, iso- $\mathrm{C}_{14: 0}(1.50 \%)$, $\mathrm{C}_{14: 0}(0.81 \%), \mathrm{C}_{15: 0}(1.22 \%)$, iso- $\mathrm{C}_{16: 0}(8.98 \%), \mathrm{C}_{16: 0}$ $(5.16 \%)$, anteiso- $\mathrm{C}_{17: 0}(8.66 \%)$ and $\mathrm{C}_{17: 0}(0.55 \%)$. The profile of fatty acids is an effective differentiating character between strain $\mathrm{Nari11}^{\mathrm{T}}$ and $M$. algeriensis $\mathrm{NariEX}^{\mathrm{T}}$, which contains iso- and anteiso- $\mathrm{C}_{15: 0}$ as major components, like strain Nari1 $1 \mathrm{~A}^{\mathrm{T}}$, but not iso- $\mathrm{C}_{17: 0}$ (Table 2).

Whole-cell sugars consisted of galactose and ribose, but no other diagnostic sugars according to Lechevalier \& Lechevalier (1970) were detected.

Strain Nari11A $\mathrm{A}^{\mathrm{T}}$ corresponded to the type strain of $M$. algeriensis in displaying LL-diaminopimelic acid as the diamino acid of the peptidoglycan and in its menaquinone profile, which contained MK-7, MK-6 and MK-8 in an approximate molar ratio of $94: 1: 1$. Its polar lipid pattern differed from that of $M$. algeriensis by the absence of the unidentified minor lipid components PL1, PL2, PL5 and L (see Fig. S4 of Addou et al., 2012). The polar lipids PL1 and PL2 of strain Nari11 $\mathrm{A}^{\mathrm{T}}$ (Fig. 2, this paper) may correspond to PL3 and PL4, respectively, of $M$. algeriensis NariEX $^{\mathrm{T}}$ (Addou et al., 2012).

Several phenotypic and chemotaxonomic characteristics differentiate the new isolate from $M$. algeriensis, such as colony morphology, inability to utilize organic compounds as carbon sources, to hydrolyse urea and to reduce nitrate, $\mathrm{G}+\mathrm{C}$ content, polar lipid pattern and cellular fatty acids. These differences, together with the strictly halophilic nature of strain Nari11 $\mathrm{A}^{\mathrm{T}}$, confirmed the distinct species status of this strain, as shown by phylogenetic data based on the $16 \mathrm{~S}$ rRNA gene sequence.

On the basis of significant phenotypic, phylogenetic and chemotaxonomic differences between strain Nari1 $1 \mathrm{~A}^{\mathrm{T}}$ and 
Table 2. Cellular fatty acid profiles of strain Nari11 $A^{\top}$ and $M$. algeriensis NariEX ${ }^{\top}$

Values are percentages of total fatty acids. -, Not detected/not reported. Data for $M$. algeriensis $\mathrm{NariEX}^{\mathrm{T}}$ were taken from Addou et al. (2012).

\begin{tabular}{|lcc|}
\hline Fatty acid & Strain Nari11A $^{\mathbf{T}}$ & M. algeriensis NariEX $^{\mathbf{T}}$ \\
\hline $\mathrm{C}_{10: 0}$ & - & 0.39 \\
$\mathrm{C}_{12: 0}$ & - & 0.21 \\
iso- $_{11: 0}$ & 0.12 & - \\
iso- $_{13: 0}$ & 0.85 & 1.25 \\
anteiso- $\mathrm{C}_{13: 0}$ & 0.38 & 0.20 \\
iso- $\mathrm{C}_{14: 0}$ & 1.50 & 1.59 \\
$\mathrm{C}_{14: 0}$ & 0.81 & 3.12 \\
iso- $\mathrm{C}_{15: 0}$ & 34.77 & 59.13 \\
anteiso- $\mathrm{C}_{15: 0}$ & 19.38 & 18.18 \\
$\mathrm{C}_{15: 0}$ & 1.22 & 0.73 \\
iso- $\mathrm{C}_{16: 0}$ & 8.98 & 1.84 \\
$\mathrm{C}_{16: 0}$ & 5.16 & 4.62 \\
iso- $\mathrm{C}_{17: 0}$ & 17.63 & 6.66 \\
anteiso- $\mathrm{C}_{17: 0}$ & 8.66 & 1.54 \\
$\mathrm{C}_{17: 0}$ & 0.55 & - \\
$\mathrm{C}_{18: 1} \omega 9 \mathrm{c}$ & - & 0.26 \\
\hline
\end{tabular}

M. algeriensis, strain Nari11 $\mathrm{A}^{\mathrm{T}}$ represents a novel species of the genus Melghirimyces, for which the name Melghirimyces thermohalophilus sp. nov. is proposed.

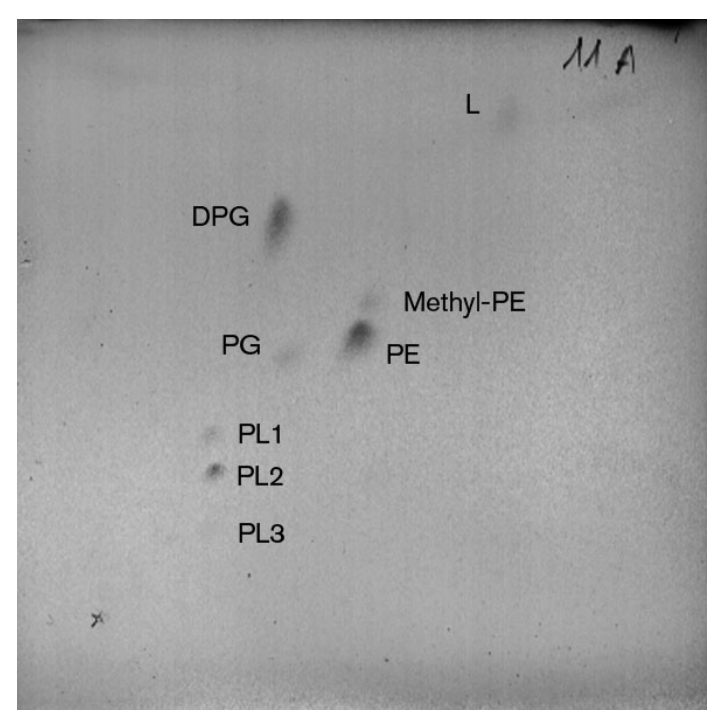

Fig. 2. Polar lipids of strain Nari1 $1 A^{\top}$ after two-dimensional TLC and detection with molybdatophosphoric acid and heating at $200{ }^{\circ} \mathrm{C}$ for 10 min. DPG, Diphosphatidylglycerol; PE, phosphatidylethanolamine; PG, phosphatidylglycerol; methyl-PE, phosphatidylmonomethylethanolamine; PL1-3, unknown phospholipids; L, unknown lipid.

\section{Description of Melghirimyces thermohalophilus sp. nov.}

Melghirimyces thermohalophilus (ther.mo.ha.lo'phi.lus. Gr. n. thermê heat; Gr. n. hals, halos salt; Gr. masc. adj. philos loving; N.L. masc. adj. thermohalophilus heat- and saltloving).

Aerobic and Gram-positive-staining. Forms brown substrate mycelium and light-brown aerial mycelium on ISP2 medium. Beige aerial and substrate mycelium are formed on ISP1, ISP6 and nutrient agar. Growth occurs at 43$60{ }^{\circ} \mathrm{C}, 5-20 \%(\mathrm{w} / \mathrm{v}) \mathrm{NaCl}$ and $\mathrm{pH} 5-10$. Does not use carbohydrates, amino acids or organic acids as sole carbon sources. Able to degrade gelatin, aesculin, arbutin and casein, but not xanthine, hypoxanthine, tyrosine, starch, xylan or cellulose. Major fatty acids are iso- $\mathrm{C}_{15: 0}$, anteiso$\mathrm{C}_{15: 0}$ and iso- $\mathrm{C}_{17: 0}$. MK-7 is the major menaquinone; $\mathrm{MK}-$ 6 and MK-8 are minor menaquinones (approximate molar ratio 94:1:1). The polar lipid pattern consists of phosphatidylglycerol, diphosphatidylglycerol, phosphatidylethanolamine, phosphatidylmonomethylethanolamine and three unidentified phospholipids. Whole-cell sugars consist of galactose and ribose, but no diagnostic sugars are detected. The DNA G+C content of the type strain is $53.4 \mathrm{~mol} \%$.

The type strain is Nari11A ${ }^{\mathrm{T}}\left(=\mathrm{DSM} 45514^{\mathrm{T}}=\mathrm{CCUG}\right.$ $\left.60050^{\mathrm{T}}\right)$, isolated from soil of an Algerian salt lake.

\section{Acknowledgements}

Manon Joseph from IRD Marseille, France, is gratefully acknowledged for realizing electron microscopy. The authors thank Mrs Anika Wasner and Mrs Birgit Grün (both DSMZ) for excellent technical assistance.

\section{References}

Addou, A. N., Schumann, P., Spröer, C., Hacene, H., Cayol, J.-L. \& Fardeau, M.-L. (2012). Melghirimyces algeriensis gen. nov., sp. nov., a member of the family Thermoactinomycetaceae, isolated from a salt lake. Int J Syst Evol Microbiol 62, 1491-1498.

Altschul, S. F., Madden, T. L., Schäffer, A. A., Zhang, J., Zhang, Z., Miller, W. \& Lipman, D. J. (1997). Gapped BLAST and PSI-BLAST, a new generation of protein database search programs. Nucleic Acids Res 25, 3389-3402.

Cashion, P., Holder-Franklin, M. A., McCully, J. \& Franklin, M. (1977). A rapid method for the base ratio determination of bacterial DNA. Anal Biochem 81, 461-466.

Cole, J. R., Wang, Q., Cardenas, E., Fish, J., Chai, B., Farris, R. J., Kulam-Syed-Mohideen, A. S., McGarrell, D. M., Marsh, T. \& other authors (2009). The Ribosomal Database Project: improved alignments and new tools for rRNA analysis. Nucleic Acids Res 37 (Database issue, ), D141-D145.

Collins, M. D., Pirouz, T., Goodfellow, M. \& Minnikin, D. E. (1977). Distribution of menaquinones in actinomycetes and corynebacteria. J Gen Microbiol 100, 221-230.

Cowan, T. (1974). Cowan and Steel's Manual for the Identification of Medical Bacteria, 2nd edn. Cambridge: Cambridge University Press. 
Embley, T. M. \& Wait, R. (1994). Structural lipids of eubacteria. In Chemical Methods in Prokaryotic Systematics, pp. 141-147. Edited by M. Goodfellow \& A. G. O'Donnell. New York: Wiley.

Fardeau, M.-L., Ollivier, B., Patel, B. K. C., Magot, M., Thomas, P., Rimbault, A., Rocchiccioli, F. \& Garcia, J.-L. (1997). Thermotoga hypogea sp. nov., a xylanolytic, thermophilic bacterium from an oilproducing well. Int J Syst Bacteriol 47, 1013-1019.

Felsenstein, J. (1985). Confidence limits on phylogenies: an approach using the bootstrap. Evolution 39, 783-791.

Gordon, R. E. (1966). Some criteria for the recognition of Nocardia madurae (Vincent) Blanchard. J Gen Microbiol 45, 355-364.

Gordon, R. E. \& Mihm, J. M. (1957). A comparative study of some strains received as nocardiae. J Bacteriol 73, 15-27.

Gordon, R. E., Barnett, D. A., Handerhan, J. E. \& Pang, C. H.-N. (1974). Nocardia coeliaca, Nocardia autotrophica, and the nocardin strain. Int J Syst Bacteriol 24, 54-63.

Groth, I., Schumann, P., Weiss, N., Martin, K. \& Rainey, F. A. (1996). Agrococcus jenensis gen. nov., sp. nov., a new genus of actinomycetes with diaminobutyric acid in the cell wall. Int J Syst Bacteriol 46, 234239.

Guérin-Faublée, V., Karray, S., Tilly, B. \& Richard, Y. (1992). Actinomyces pyogenes: étude bactériologique conventionnelle et sur galeries Api de 103 souches isolées chez les ruminants. Ann Rech Vet 23, 151-160 (in French).

Hall, T. A. (1999). BioEdit: a user-friendly biological sequence alignment editor and analysis program for Windows 95/98/NT. Nucleic Acids Symp Ser 41, 95-98.

Hatayama, K., Shoun, H., Ueda, Y. \& Nakamura, A. (2005). Planifilum fimeticola gen. nov., sp. nov. and Planifilum fulgidum sp. nov., novel members of the family 'Thermoactinomycetaceae' isolated from compost. Int J Syst Evol Microbiol 55, 2101-2104.

Joffin, J.-N. \& Leyral, G. (2006). Microbiologie technique, 4th edn, vol. 1. Bordeaux: CRDP d'Aquitaine.

Jukes, T. H. \& Cantor, C. R. (1969). Evolution of protein molecules. In Mammalian Protein Metabolism, vol. 2, pp. 211-232. Edited by H. N. Munro. New York: Academic Press.

Lányí, B. (1987). Classical and rapid identification methods for medically important bacteria. Methods Microbiol 19, 1-67.

Larsen, H. (1986). Halophilic and halotolerant microorganisms: an overview and historical perspective. FEMS Microbiol Rev 39, 3-7.

Lechevalier, M. P. \& Lechevalier, H. (1970). Chemical composition as a criterion in the classification of aerobic actinomycetes. Int J Syst Bacteriol 20, 435-443.

Li, J., Zhang, G. T., Yang, J., Tian, X. P., Wang, F. Z., Zhang, C. S., Zhang, S. \& Li, W. J. (2012). Marininema mesophilum gen. nov., sp. nov., a thermoactinomycete isolated from deep sea sediment, and emended description of the family Thermoactinomycetaceae. Int J Syst Evol Microbiol 62, 1383-1388.

Matsuo, Y., Katsuta, A., Matsuda, S., Shizuri, Y., Yokota, A. \& Kasai, H. (2006). Mechercharimyces mesophilus gen. nov., sp. nov. and Mechercharimyces asporophorigenens sp. nov., antitumour substanceproducing marine bacteria, and description of Thermoactinomycetaceae fam. nov. Int J Syst Evol Microbiol 56, 2837-2842.

Mesbah, M., Premachandran, U. \& Whitman, W. B. (1989). Precise measurement of the $\mathrm{G}+\mathrm{C}$ content of deoxyribonucleic acid by high performance liquid chromatography. Int J Syst Bacteriol 39, 159-167.

Minnikin, D. E., Collins, M. D. \& Goodfellow, M. (1979). Fatty acid and polar lipid composition in the classification of Cellulomonas, Oerskovia and related taxa. J Appl Bacteriol 47, 87-95.

Saitou, N. \& Nei, M. (1987). The neighbor-joining method: a new method for reconstructing phylogenetic trees. Mol Biol Evol 4, 406425.

Schumann, P. (2011). Peptidoglycan structure. Methods Microbiol 38, 101-129.

Shirling, E. B. \& Gottlieb, D. (1966). Methods for characterization of Streptomyces species. Int J Syst Bacteriol 16, 313-340.

Sierra, G. (1957). A simple method for the detection of lipolytic activity of micro-organisms and some observations on the influence of the contact between cells and fatty substrates. Antonie van Leeuwenhoek 23, 15-22.

Staneck, J. L. \& Roberts, G. D. (1974). Simplified approach to the identification of aerobic actinomycetes by thin-layer chromatography. Appl Microbiol 28, 226-231.

Stead, D. E., Sellwood, J. E., Wilson, J. \& Viney, I. (1992). Evaluation of a commercial microbial identification system based on fatty acid profiles for rapid, accurate identification of plant pathogenic bacteria. J Appl Bacteriol 72, 315-321.

Tamaoka, J. \& Komagata, K. (1984). Determination of DNA base composition by reversed-phase high-performance liquid chromatography. FEMS Microbiol Lett 25, 125-128.

Thabet, O. B., Fardeau, M.-L., Joulian, C., Thomas, P., Hamdi, M., Garcia, J.-L. \& Ollivier, B. (2004). Clostridium tunisiense sp. nov., a new proteolytic, sulphur-reducing bacterium isolated from an olive mill wastewater contaminated by phosphogypse. Anaerobe 10, 185190.

Tsukamura, M. (1966). Adansonian classification of mycobacteria. J Gen Microbiol 45, 253-273.

Von Jan, M., Riegger, N., Pötter, G., Schumann, P., Spröer, C., Rohde, M., Feunscht, E., Labeda, D. P. \& Klenk, H.-P. (2011). Kroppenstedtia eburnea gen. nov., sp. nov., a novel thermoactinomycete isolated by environmental screening, and emended description of the family Thermoactinomycetaceae Yassin et al. 2009. Int J Syst Evol Microbiol 61, 2304-2310. 